\title{
TITLE:
}

\section{THE TAXONOMICAL OUTLINE OF CHAETOGNATHA}

AUTHOR(S):

Tokioka, Takasi

\section{CITATION:}

Tokioka, Takasi. THE TAXONOMICAL OUTLINE OF CHAETOGNATHA. PUBLICATIONS OF THE SETO MARINE BIOLOGICAL LABORATORY 1965, 12(5): 335-357

ISSUE DATE:

1965-03-10

URL:

http://hdl.handle.net/2433/175381

RIGHT: 


\title{
THE TAXONOMICAL OUTLINE OF CHAETOGNATHA ${ }^{13}$
}

\author{
TAKASI TOKIOKA
}

Seto Marine Biological Laboratory

The monographic work by RitTer-ZÁHOnY (1911) "Revision der Chätognathen" appeared in the report of the Deutsche Südpolar-Expedition, 1901-3, may be regarded as the base for the taxonomy of Chaetognatha which has been accepted so far. In that paper, the following 27 species belonging to 6 genera were given, besides 16 species were listed as species incertae. And other 44 names were treated there as synonyms of valid species.

List 1. Valid species listed by RITTER-ZÁHONY (1911).
1. Sagitta hexaptera
15. Sagitta neglecta
2. Sagitta maxima
16. Sagitta regularis
3. Sagitta lyra
17. Sagitta minima
4. Sagitta gazellae
18. Sagitta decipiens
5. Sagitta enflata
19. Sagitta planctonis
6. Sagitta setosa
20. Sagitta macrocephala
7. Sagitta elegans
21. Pterosagitta draco
8. Sagitta bipunctata
22. Spadella cephaloptera
9. Sagitta robusta
23. Spadella schizoptera
10. Sagitta helenae
24. Eukrohnia hamata
11. Sagitta friderici
25. Eukrohnia fowleri
12. Sagitta bedoti
26. Heterokrohnia mirabilis
13. Sagitta pulchra
27. Krohnitta subtilis
14. Sagitta serratodentata

List 2. Species incertae by RITTER-ZÁHONY (1911).
*1. Sagitta britannica
*7. Sagitta helgolandica
*2. Sagitta coreana
*8. Sagitta hispida
3. Sagitta darwini
*9. Sagitta levis
4. Sagitta diptera
*10. Sagitta longicauda
*5. Sagitta euxina
*11. Sagitta orientalis
*6. Sagitta gegenbauri
*12. Spadella profunda

1) Contributions from the Seto Marine Biological Laboratory, No. 430.

Publ. Seto Mar. Biol. Lab., XII (5), 1965. (Article 26) 
13. Sagitta rostrata

*14. Sagitta tenuis
15. Sagitta triptera

16. Krohnia viridis

Of the species incertae, S. darwini, S. diptera and S. triptera were referred to $S$. hexaptera with some questions and so was $S$. rostrata to $S$. selosa. And K. viridis is AIDA's misrecord for Krohnitta pacifica. Then eleven species marked with asterisk were left without being referred to any valid species. Forty-one years later, I made a general review on chaetognaths of the Indo-Pacific (Chaetognaths of the Indo-Pacific; Annot. Zool. Japon., Vol. 25, Nos. 1-2, 1952, pp. 307-316) and there were enumerated the world chaetognaths as follows.

List 3. Valid taxa listed by TokIOKA (1952).
1. Bathyspadella edentata
2. Eukrohnia hamata
3. Heterokrohnia mirabilis
4. Krohnitta pacifica
5. Krohnitta subtilis
6. Krohnittella boureei
7. Pterosagitta draco
8. Sagitta bedfordii
9. Sagitta bedoti
10. Sagitta bedoti f. minor
11. Sagitta bipunctata
12. Sagitta bombayensis
13. Sagitta crassa
14. Sagitta crassa f. naikaiensis
15. Sagitta decipiens
16. Sagitta delicata
17. Sagitta elegans
18. Sagitta enflata
19. Sagitta euxina
20. Sagitta ferox
21. Sagitta friderici
22. Sagitta helenae
23. Sagitta hexaptera

-24. Sagitta lyra

25. Sagitta macrocephala

26. Sagitta minima

27. Sagitta neglecta

28. Sagitta oceanica

29. Sagitta parva

30. Sagitta planctonis

31. Sagitta pulchra

32. Sagitta regularis

33. Sagitta robusta

34. Sagitta serratodentata atlantica f. typica

35. Sagitta serratodentata atlantica

f. pseudoserratodentata

36. Sagitta serratodentata atlantica f. tasmanica

37. Sagitta serratodentata pacifica

38. Sagitta setosa

39. Sagitta tropica

40. Sagitta tumida

41. Spadella cephaloptera

42. Spadella schizoptera

These forty-two taxa included 37 species, 1 subspecies and 4 forms. Besides, next 11 species were treated as doubtful species.

List 4. Doubtful species by TokIOKA (1952).
1. Eukrohnia fowleri
3. Sagitta levis
2. Sagitta coreana
4. Sagitta longicauda 
5. Sagitta maxima

6. Sagitta orientalis

7. Sagitta tenuis

8. Spadella moretonensis
9. Spadella musculosa

10. Spadella profunda

11. Zahonya cestoda

Sagitta gazellae was regarded there as a synonym of $S$. lyra. Of the remaining eleven forms of the List 2 , S. euxina was accepted as a valid species and $S$. hispida was treated as a synonym of S. ferox, while Spadella musculosa treated by RITTER-ZAHONY as a synonym of $S$. cephaloptera was regarded then as a doubtful species possibly distinct from S. cephaloptera. Sagitta britannica, $S$. gegenbauri and $S$. helgolandica were put outside the consideration, as the original descriptions were inaccessible to me. Actually, even if those descriptions are read by myself, I wont be able to give any more comments on those vaguely defined forms than RitTER-ZÂHNOY did long ago. Fifteen synonyms appeared after the publication of RITTER-ZÁHONY's monograph were respectively referred to the species considered to be valid, although the following two papers were overlooked at that time: Hsü's paper (1943) including a new species, Sagitta multidentata (non KROHN, 1853), and MAwson's paper (1944) reporting two new species of Spadella, S. sheardi and S. johnstoni.

Many important papers have been published since the above-mentioned lists were prepared by me, and these have brought a significant number of alternations and additions to the list of the world's chaetognoths. PIERcE's works (1951, 53, 58 and 62) cleared the validity of Sagitta hispida and Sagitta tenuis, and this was confirmed by subsequent papers by Tokioka (1955), SuÁrez (1955 and 60), Furnestin (1959, 60 and 62 c) and BAinbridge (1960). David studied the morphology and distribution of the chaetognaths occurring in the Antarctic and adjacent seas and ascertained that Sagitta gazellae (1955) and Sagitta zetesios (1956) are valid species. Besides, he found two new species from the Antarctic waters: Sagitta marri (1956) and Eukrohnia bathyantarctica (1958). It was found that the individuals which had been known from the warm-water regions under the name of Sagitta gazellae were really the gazellae-forms of Sagitta lyra probably representing the younger stages of that species. This is very interesting when the matter is noted in relation to the life cycle of Sagitta lyra suggested by Furnestin (1962a). Furnestin (1958 and 62b) examined Sagitta euxina from the Black Sea and Sagitta setosa from the North Sea, the Mediterranean Sea and the Black Sea and concluded that the former should be treated as a variety of the latter. On the other hand, the validity of Sagitta maxima and Eukrohnia fowleri has been recognized by various authors (DAvID, 1958 a and b). Especially, Alvariño (1962) found out a marked difference of the arrangement of the nerve cord between S. maxima and S. lyra and put a period to the questions concerning the validity of S. maxima. In addition, the following 14 new species and one form have been described. 
1. Pterosagitta besnardi VAnnucci and Hosoe, 1952

2. Sagitta selkirki FAGETTI, 1958 b

3. Sagitta ferox f. americana Tokioka, 1959

4. Sagitta neodecipiens ToKIoKA, 1959

5. Sagitta gloriae PRADO, 1960

6. Sagitta bierii AlvariÑo, 1961

7. Sagitta euneritica AlvariÑo, 1961

8. Sagitta peruviana Sund, 1961

9. Sagitta popovicii SUND, 1961

10. Sagitta scrippsae Alvariño, 1962

11. Eukrohnia bathypelagica AlvariÑo, 1962

12. Spadella nana OwRE, 1963

13. Spadella pulchella OwRE, 1963

14. Sagitta johorensis Pathansali \& Tokioka, 1963

15. Sagitta demipenna Tokioka \& Pathansali, 1963

Further, Spadella cephaloptera f. angulata was raised to the rank of species by Tokioka and Pathansali (1964).

Taking the above-mentioned amendments and additions into the consideration, 65 taxa listed in next section are considered to be valid in my opinion. Eleven species still remain as doubtful species, while others are treated as synonyms. About three fourths of these taxa belong to the genus Sagitta, and thus there is found a high grade of variety in Sagitta. Some species resemble one another so closely that they may be better treated as subspecies, varieties or ecological forms of a single species, while in some couples one species may differ from the other so much that if the forms in the preceding case are reasonably treated as species, then it is desirable to prepare some genera to fit in such cases. Thus, the necessity of subdividing the genus Sagitta has been recognized. Tokioka and Pathansali (1963) proposed two subgenera, Aidanosagitta and Serratosagitta, to cover 18 described taxa, but other about thirty ones are still left confused. An attempt to classify these into some groups is to be made in next section. (cf. Alvariño 1963, 136-141)

As to further classification above the level of the genus, I am aware of so far Family Sagittidae shown in "C. CL.Aus-K. GrobBen: Lehrbuch der Zoologie (1905)" and Family Amiskwiidae W ALCOTT given to a single fossil species, and Class Sagittoidea found also in Claus-GrobBen's text-book. It is not known whether Amiskwiidae is included in Sagittoidea or not. The group name Chaetognatha has been used for Order, Class or Phylum. ABRIC (1905) rearranged the species of Chaetognatha known at that time into nine new genera by fin characters and then divided those genera into two groups by the situation of the anus. 
Gastroproctidae

Scottochaetus-Given to a form figured by T. ScoTT (1896: Additions to the fauna of the Firth of Forth, Pt. VIII-Annelid parasite of Sagitta, Ann. Rep. Fish. Board of Scotland, Vol. 14 , p. 165, pl. 4, figs. 16-17) without any name nor descriptions. The fin system consisting of paired fins and caudal fin is completely continuous or adjoining parts of the system are in contact with each other; the separation of the caudal fin from the whole system is foreshown.

Krohnochaetus-Type species is Krohnia foliaceus AIDA. This genus resembles the preceding one, but without a continuation between the lateral fins and the caudal fin. Lateral fins are extended on the tail segment as well as on the most part of the trunk.

Lyrochaetus-Type species is Sagitta lyra KROHN. Each lateral fin is divided on the trunk, but incompletely.

Sagittochaetus-Given for Sagitta auct. The separation of the lateral fin is made completely.

Conantochaetus-Type species is Spadella schizoptera CONANT. The separation of the lateral fin occurs at the trunk-tail septum; the tail segment is as long as the trunk; non-pelagic.

Spadellochaetus -Given for Spadella auct. and Krohnia hamata (MöвIUs). This genus resembles Krohnochaetus, but the part of the lateral fin corresponding to the anterior fin of Sagittochaetus is not developed.

Grassiochaetus-Type species is Sagitta Claparedi GRAssI. This genus resembles Spadellochaetus, but the lateral fins and the caudal fin are continuous to each other.

Dracochaetus - The fin system is similar to that of Spadellochaetus; a pair of bristle bundles on lateral sides of the trunk. Three species are included; Dr. Krohni, Dr. Strodtmanni, Dr. Vougai BÉRANECK.

Notoproctidae

Gourretochaetus-Type species is Spadella Marioni GoUrReT.

This classification is, however, evidently unnatural and the principal characters of respective genera are based on incomplete or inaccurate figures or descriptions; none of actual examinations of real specimens was made. Needless to say about the dorsal situation of the anus for Notoproctidae. Thus, the classification was not accepted by successive authors.

Since that no attempt has been made to establish further classification system of Chaetognatha. So is the case in Hymas's "The Invertebrates, Vol. V (1959)". Nevertheless, it seems to me unreasonable to leave all the extant genera of Chaetognatha in a single group, because some of the structural differences found between certain genera are considered to be of a significant systematic importance. Thus a proposal of a new classification of Chaetognatha, treated here as a phylum, is presented as follows.

PHYLUM CHAETOGNATHA (LeuCKarT, 1894)

\section{† 1. Class Archisagittoidea nov.}

Family Amiskwiidae WALCOTt, 1911

Genus Amiskwia WALCOTT, 1911

Only a single extinct species A. sagittiformis WALCOTT, 1911 is known by 
three fossil specimens from the Middle Cambrian of British Columbia. Owre and BAYER (1962) are skeptical to treat the genus as belonging to Chaetognatha and interpret it as a member of Nemertina, possibly related to forms such as Nectonemertes. The body size much larger than in extant forms, the existence of a pair of remarkable cephalic tentacles and the location of the anus near the caudal end of the body are unusual for chaetognaths. Moreover, it is strange that any traces of reproductive organs which are so massive in mature individuals of extant forms are not left on these fossils. I am rather inclined to the opinion of OWRE and BAYER. At the same time, however, I cannot definitely reject the possibility that Amiskwia might represent an ancient form of recent chaetognaths, on the basis of the comparison between the so old Cambrian fossils and to-day's chaetognaths. Of the strange features of Amiskwia mentioned above, the most important one must be the terminal situation of the anus, and essentially this is not unusual for Chaetognaths as the endodermal septum stretches along the sagittal axis of the body from the pharynx to the caudal end of the body in the larval stage of chaetognaths. Thus, when Amiskwia is admitted as a member of Chaetognatha, a special group must be established to hold it, and the group, Class Archisagittoidea is proposed here for it, should be characterized by the location of the anus at the caudal end of the body. Other external features such as the existence of a pair of stout cephalic tentacles and others are regarded as being of the family or generic importance.

\section{Class Sagittoidea Claus and Grobben, 1905}

The class consists of extant forms. The anus opens on the ventral side just before the trunk-tail septum, far anterior to the caudal end of the body. Nine genera have been included unless further division of the genus Sagitta is made. Of the characteristics differentiating these genera one another, the existence of the ventral transverse musculature and the peculiar appearance of hooks and teeth unique to Krohnitta are most remarkable and considered to be of an essential importance. The differences found in the appearance of fins and number of tooth-rows are less significant as is suspected from the ontogenical observations.

Now, there are two groups of chaetognaths differing distinctly from each other in the mode of life; one is the littoral group represented by a few members of Spadella and the other is the pelagic group containing a large number of species mostly belonging to the genus Sagitta in the sense hitherto be used. Pelagic species are mostly devoid of the ventral transverse musculature and provided with less glandular structures on the body surface, except for a few deep-water forms. Contrarily, members of Spadella are all provided with the ventral transverse musculature in the coelom and richer glandular 
structures on the body surface. It seems to me that pelagic forms of a simpler body structure were derived from the littoral forms with creeping ability and with more complicated body structures. The reverse process cannot be impossible, but it seems more improbable than the preceding process. For this reason, the existence of the ventral transverse musculature is regarded here as a basic feature separating the primitive forms from the advanced ones, and the peculiarity found in hooks and teeth of Krohnitta is considered to be a sign showing a high grade of specialization. Thus, the class is divided into the following three main groups.

1. Order Phragmophora nov. Phragmatic structure made of the ventral transverse musculature in the coelom. Usually various kinds of glandular structures are seen on the body surface, in the neck or cephalic region.

2. Order Aphragmophora nov. Phragmatic structure is absent and thus the whole coelom is entirely hollow. Glandular structures on the body surface are scarcely developed.

1. Suborder Ctenodontina nov. Hooks are curved gently and tooth-rows are comb-shaped, teeth are slender.

2. Suborder Flabellodontina nov. Hooks are curved rather abruptly and teeth are stouter than in Ctenodontina and arranged in a fan shape.

\$Order Phragmophora The order is divided into two families.

I. Family Spadellidae nov. Littoral, usually resting on algae, stones or other objects on the bottom, but retaining the ability of creeping and swimming. Tail segment is relatively large. One or two pairs of lateral fins. Anterior and posterior rows of teeth, which show a trend to the degeneration. Corona ciliata on the neck, wider than long.

(1) Genus Spadella LANGerhans, 1880

1. S. cephaloptera (BUScH, 1851)

Sagitta cephaloptera $\mathrm{BusCH}, 1851$

*Sagitta Batziana GIARD, 1874

*Sagitta Claparedi Grassi, 1883

*Sagitta gallica PAGENSTEChER, 1863

*Sagitta Mariana LEWFS, 1858

*Spadella parvula Moltschanoff, 1909

*Sagitta pontica UlJanin, 1870

2. S. angulata (TokiokA, 1951)

Spadella cephaloptera f. angulata TокIокA, 1951

3. S. moretonensis JoHNSTON \& TAYLOR, 1919

\footnotetext{
* Synonymy after RITTER-ZÁHONY (1911).
} 
4. S. schizoptera ConANT, 1895

5. S. sheardi Mawson, 1944

6. S. johnstoni MAwson, 1944

7. S. nana OwRE, 1963

8. S. pulchella OWRE, 1963

S. cephaloptera and S. angulata are devoid of any adherent apparatus, while other six species have each adherent apparatuses of various shapes. In $S$. moretonensis the apparatuses are rudimentary and arranged asymmetrically. In other five species, the apparatuses are well developed in a paired arrangement. It is not impossible that at least some of the five species, S. schizoptera, S. sheardi, S. johnstoni, S. nana and S. pulchella, represent only different intraspecific variants of a single species. Spadella musculosa and Spadella profunda described by Doncaster in 1903 are left as questionable species. It seems rather dangerous to abandon these deep-water species, as some valid species of Spadella are collected from the waters of a considerable depth.

II. Family Eukrohniidae nov. Pelagic, tail segment is comparatively short. One pair of lateral fins, each beginning far anterior to the trunk-tail septum. Anterior tooth-row or both anterior and posterior tooth-rows may be missing in some genera. So far as it is described, the conona ciliata begins at the posterior edge of the brain and ends at the neck region. All valid forms are known from the deep water at least in the warm-water regions.

(2) Genus Eukrohnia RitTeR-ZÁHONY, 1909

9. E. hamata (MöвIUS, 1875)

Sagitta hamata MöвIUs, 1875

*Krohnia hamata var. borealis MOLTSCHANOFF, 1907

Eukrohnia hamata var. antarctica JOHNSTON \& TAYLOR, 1921

Krohnia foliacea AIDA, 1897

Eukrohnia richardii GERMAIN \& JOUBIN, 1912

10. E. fowleri RITTER-ZÁHONY, 1909

11. E. bathyantarctica DAvID, 1958

12. E. bathypelagica Alvariño, 1962

The last two species are separated from E. hamata only by exact differences, although their distributions are said strictly limited.

(3) Genus Heterokrohnia RITTER-ZÁHONY, 1911

13. H. mirabilis RITTER-ZÁHONY, 1911 
(4) Genus Bathyspadella ToKIokA, 1939

14. B. edentata TokiokA, 1939

Next two genera, respectively represented by a single species, are placed here provisionally with some doubts.

\section{Genus Krohnittella Germain \& Joubin, 1912}

K. boureei Germain \& Joubin, 1912

Genus Zahonya Oye, 1918

$Z$. cestoda Oye 1918

Two specimens of Krohnittella boureei were collected once from the depths north of the Canary Islands. No descriptions are given for the ventral transverse musculature, the intestinal diverticula, the eye-pigment and the collarette. Thus, the exact situation of this genus is quite obscure. However, one pair of lateral fins, the corona ciliata confined to the head, the complete absence of teeth, and the large depth of the inhabiting layer seem to allege that the genus is allied to genera of Eukrohniidae. It is possible that the existence of the ventral transverse musculature was overlooked. On the dorsal aspect of the head of this species figured by GERMAIN \& JoubIn, no pigment is indicated in each eye. The species resembles Bathyspadella edentata in the complete absence of teeth, but differs distinctly from it in that the tail segment is much shorter.

Zahonya cestoda was once collected from the surface water of the eastern Java Sea. The whole trunk and the tail segment are provided with the ventral transverse musculature. The corona ciliata is described to be confined to the head. But it is very probable that the outline of the pharynx was mistaken for the corona ciliata in this case. Other features are quite the same as in general species of Ctenodontina of Aphragmophora. The comment given to this species in my previous paper (1952, p. 312) may be reproduced here again to show a possible interpretation about the species,- "It is a noteworthy fact that some species with strongly developed musculature assume an appearance, when they are in a slightly contracted state, as if they were provided with a transverse musculature along the whole body. Thus, this species is possibly no more than a small individual of S. robusta (or S. ferox) in such a state." If this species is proved to be valid, then the habitat, the surface layer in the tropical waters, must be quite unusual for the members of the family. 


\section{§Order Aphragmophora}

\section{Suborder Ctenodontina}

III. Family Sagittidae Claus \& GROBbEN 1905 Two pairs of lateral fins. The former genus Sagitta is now splitted into next nine genera.

(5) Genus Sagitta (s. str.) QuOY \& GAIMARD, 1827

The corona ciliata is very elongate, begins just behind the brain and stretches posteriorly onto the dorsal side of the anterior portion of the trunk. Intestinal diverticula are absent. Lateral fins are thoroughly set with rays.

15. S. bipunctata QuOY \& GAIMARD, 1827

(Based on the description given by RITTER-ZÁHONY, 1911.)

Sagitta californica MICHAEL, 1913

*Spadella Marioni Gourret, 1884

*Sagitta multidentata KROHN, 1853

16. S. setosa MüLleR, 1847

* Sagitta Germanica LetTCKART, 1847

*? Sagitta rostrata $\mathrm{BuscH}, 1851$

17. S. setosa var. euxina (Moltschanoff, 1909)

Sagitta euxina Moltschanofr, 1909

18. S. tenuis Conant, 1896

Sagitta popovicii SuND, 1961

19. S. friderici RitTER-ZÁHONY, 1911

Sagitta euneritica ALVARIÑo, 1961

Sagitta peruviana SuND, 1961

20. S. helenae Ritter-ZÁHONY, 1910

21. S. bombayensis LELE \& GAE, 1936

S. bipunctata described by some authors in earlier years represent hexaptera, setosa, elegans, bedoti or rarely Spadella cephaloptera.

As to the distinction between $S$. tenuis and S. friderici see TokiokA's paper of 1961. In that paper, the proportion of the anterior part of the posterior fin above the trunk-tail septum to the posterior part of the fin below the septum is taken as one of the important clues. Generally the ratio is smaller in S. tenuis than in S. friderici. It is, however, not impossible that the development of the anterior part of the posterior fin above the septum might be retarded by the fast development of the ovary in the structural connection. More observations and measurements made statistically on various species are desirable to settle this problem. 
(6) Genus Zonosagitta nov.

The corona ciliata as in Sagitta (s. str.), intestinal diverticula absent. Lateral fins are each provided with a very remarkable rayless-zone.

22. Z. bedoti (BÉRANEck, 1895)

Sagitta bedoti BÉRANECK, 1895

23. Z. bedoti f. minor (ТокIокA, 1942)

Sagitta bedoti f. minor TоктоKA, 1942

Sagitta bedoti minor: HAMON, 1956

?Sagitta polyodon DONCASTER, 1902

24. Z. pulchra (DoNCAster, 1902)

Sagitta pulchra DONCASTER, 1902

Sagitta weberi OYE, 1918

$Z$. bedoti f. minor from the tropical waters matures at much smaller body size (about $10 \mathrm{~mm}$ ) than that of mature individuals of the typical form which may be up to $30 \mathrm{~mm}$ in higher latitudes, the Yellow Sea or the Japan Sea. Such larger individuals are noted by Alvariño (1963) as bedoti f. large. Recently, further smaller form of $Z$. bedoti was found by PATHANSALI in certain inlets of Malay Peninsula. This form matures at $6-7 \mathrm{~mm}$ and thus may represent a special ecological form of the species; its description will be given in a future paper. The existence of the rayless-zone seems to be a significant character as the fin rays are generated ontogenically at the very beginning of the fin formation and the arrangement of rays is quite regular in adult forms.

\section{(7) Genus Serratosagitta Tokioka \& Pathansali, 1963}

Originally defined as a subgenus. This genus conforms to Sagitta (s. str.) in features concerning the corona ciliata, intestinal diverticula and lateral fins, but differs from the latter in having serrated hooks, much smaller and elongate pigmented area of the eye, seminal vesicles situated just behind the posterior fin and widely apart from the tail fin and a remarkable swelling near the middle of the vas deferens. The serrated aspect of the hook edge is not a very unusual feature for members of Sagittidae, as under high magnification the hook edge manifests sometimes an insignificant array of faint prominences regularly or irregularly arranged in some species, and thus the serrated feature of the hook can not be of a great systematic importance.*

25. S. serratodentata (KROHN, 1853)

Sagitta serrato-dentata KROHN, 1853

* This will be mentioned in dentail by Pathansali in his paper in press. 
*Sagitta serrulata Cleve, 1905

Sagitta serratodentata f. atlantica ToKIoKA, 1940

Sagitta serratodentata atlantica f. typica TokIoKA, 1952

Sagitta serratodentata atlantica ToKIOKA, 1959

26. S. pseudoserratodentata (ТокіокА, 1939)

Sagitta pseudoserratodentata ToKтоKA, 1939

Sagitta serratodentata atlantica f. pseudoserratodentata ToKIOKA, 1952

Sagitta serratodentata pseudoserratodentata TokIOKA, 1959

27. S. tasmanica (Thomson, 1947)

Sagitta serratodentata tasmanica THOMSON, 1947

Sagitta serratodentata atlantica f. tasmanica: ToKIOKA, 1952

Sagitta selkirki FAGETTI, 1958

28. S. bierii (Alvariño, 1961)

Sagitta bierii ALVARIÑo, 1961

29. S. pacifica (ToKIoKA, 1940)

Sagitta serratodentata f. pacifica ToKIOKA, 1940

Sagitta serratodentata pacifica: THOMSON, 1947

Sagitta pacifica : BIERI, 1957

S. pacifica was first defined by Tokioka as a geographical form of serratodentata, but later raised to the rank of subspecies by Thomson (1947) and then to species by BIERI (1957). S. bierii resembles very closely S. tasmanica, differing from it only in the exact appearance of the seminal vesicle. As the main distributions of $S$. tasmanica and $S$. bierii are confined to the rather cooler waters of the southern hemisphere or to the northward flows, the Humboldt Current and the affected area off the California coast and the Benguela Current, both originating in the southern cool waters, it is not impossible that these two species are identical with each other. Further studies on the morphology of the seminal vesicle are desirable. On the posterior fin, in some species, rays are sometimes missing in a narrow area around the female genital opening, although this is nearly insignificant.

\section{(8) Genus Parasagitta nov.}

The corona ciliata as in Sagitta (s. str.), lateral fins are wholly set with rays. Intestinal diverticula are present.

30. P. elegans (VERRILL, 1873)

Sagitta elegans VERRILL, 1873

*Sagitta falcidens LEIDY, 1882

Sagitta flaccida Galzow, 1909

*Sagitta germanica of some authors

*Sagitta glacialis Moltschanoff, 1907

*Sagitta gracilis VerRILL, 1885 
*Sagitta melanognatha MolTsChANOFF, 1907

* Sagitta rapax MoltsChanOFF, 1907

31. P. elegans arctica (Aurivillius, 1896)

Sagitta arctica AUrIVILlLIUS, 1896

This subspecies consists of larger individuals from the far off-shore waters in the subarctic to the arctic regions. The difference between this and typical elegans does not seem to be discontinuous. However, this subspecific distinction may be effectual when the chaetognath populations in those areas are discussed at the level of stocks.

32. P. elegans baltica (RITTER-ZÁHONY, 1911)

Sagitta elegans f. baltica RITTER-ZÁHONY, 1911

Besides the above-mentioned subspecific differentiations, the diminution of the body size of mature individuals in the enclosed environments is recorded in Lake Ogac on the northeastern coast of Canada (Dunbar, 1962).

33. P. hispida (Conant, 1895)

Sagitta hispida CONANT, 1895

Sagitta gloriae PRADO, 1960

34. P. hispida americana (TokIokA, 1959)

Sagitta ferox f. americana TokIOKA, 1959

Anterior teeth are more numerous than in the typical form.

35. P. robusta (Doncaster, 1902)

Sagitta robusta DONCASTER, 1902

Sagitta ai TokrokA, 1939

Sagitta ferox: Alvariño, 1962

36. P. ferox (DONCASTER, 1902)

Sagitta ferox DONCASTER, 1902

Sagitta equatoria GRAY, 1923

Sagitta hispida of some authors

Sagitta japonica GALzow, 1909

Sagitta robusta of many authors

I think the identification of $P$. ferox and $P$. robusta should be made after the description by Thomson (1947) based on the type specimens of Doncaster. $P$. hispida resembles these two species very closely, but differs from them in the exact appearance and situation of the seminal vesicle and number of teeth. Sagitta gloriae from Brazilian waters is considered to be a synonym of $P$. hispida.

(9) Genus Aidanosagitta TokIoKa \& PAThansali, 1963

The genus was originally defined as a subgenus. The corona ciliata begins 
below the level of eyes, intestinal diverticula are present, and lateral fins are wholly rayed. The seminal vesicle is generally situated just behind the posterior fin, being apart more or less from the base of the tail fin; in no species is the anterior glandular portion differentiated externally. The tail segment is relatively long. In most species, the distribution is limited to the inlet or neritic waters.

37. A. neglecta (AIDA, 1897)
Sagitta neglecta AIDA, 1897
* Sagitta septata DONCASTER, 1902
Sagitta trichodermis OYE, 1918

38. A. oceanica (GRAY, 1930)

Sagitta oceanica GRAY, 1930

Sagitta lacunae ToKIoKA, 1942

39. A. johorensis (Pathansali \& ToKioKa, 1963)

Sagitta johorensis PATHANSALI \& TOKIOKA, 1963

40. A. regularis (AIDA, 1897)

Sagitta regularis AIDA, 1897

41. A. bedfordii (Doncaster, 1902)

Sagitta Bedfordii Doncaster, 1902

Sagitta pseudoregularis OYE, 1918

42. A. demipenna (Tokioka \& Pathansali, 1963)

Sagitta (Aidanosagitta) demipenna TokIOKA \& PATHANSALI, 1963

43. A. crassa (ToKIoKA, 1938)

Sagitta crassa TokIOKA, 1938

Sagitta multidentata Hsن், 1943

44. A. crassa f. naikaiensis (ТокIокA, 1939)

Sagitta crassa f. naikaiensis ToKIOKA, 1939

45. A. crassa f. tumida (TokiokA, 1939)

Sagitta tumida TokıKA, 1939

46. A. delicata (ToKroKA, 1939)

Sagitta delicata TokrokA, 1939

47. A. tropica (TokiokA, 1942)

Sagitta tropica TokıokA, 1942

48. A. parva (OYE, 1918)

Sagitta parva OYE, 1918

$A$. oceanica is related very closely to $A$. neglecta, the comparison between these two species is fully discussed in the description of $S$. lacunae. I made observations on the chaetognath population of Lake Notoro of Hokkaidô Island in early September last year and in early May this year and confirmed that the chaetognath population of this lake, completely separated from the Okhotsk 
Sea by a sand bank in the winter season but communicated with the sea through a narrow and shallow canal maintained artificially during the summer season, consisted of only a single species which had been known under the name of Sagitta tumida and that the species assumed the characteristic appearance of $S$. tumida in May, but the appearance was exactly the same as that of A. crassa f. naikaiensis in September. This seems to prove that $S$. tumida is an ecological form of A. crassa and the appearance charateristic to $S$. tumida is the feature unique to the generation appeared after the winter. Further details will be given in a future paper.

\section{(10) Genus Mesosagitta nov.}

The corona ciliata begins on the neck and stretches posteriorly onto the anterior portion of the trunk. Intestinal diverticula are present. Fin rays are sparse, or missing in some parts of lateral fins. The posterior fin lies much more along the trunk than along the tail. Seminal vesicles are situated apart from the rear end of the posterior fin. Generally the members of the genus occur most frequently and abundantly in mesoplankton, although they can be fished sparsely in the surface layer.

49. M. minima (GrASSI, 1881)

Sagitta minima GRASSI, 1881

? Sagitta atlantica GRAY, 1923

50. M. decipiens (Fowler, 1905)

Sagitta decipiens FOWLER, 1905

Sagitta philippini MICHAEL, 1919

Sagitta Sibogae FowLER, 1906

51. M. neodecipiens (ToKroKA, 1959)

Sagitta neodecipiens ТокıокA, 1959

The difference between decipiens and neodecipiens is found merely in the situation of the seminal vesicle. More crucial studies are needed till the validity of neodecipiens is confirmed definitely.

\section{(11) Genus Solidosagitta nov.}

The appearance of the corona ciliata, the existence of intestinal diverticula, and the distribution of the posterior fin on the trunk and the tail are quite similar to those in the preceding genus. In the present genus, however, the distinct rayless-zone is defined on respective fins and the pigmented area of the eye is markedly small as compared with the size of the eye. The body is much stouter than in the preceding genus. All members occur in the middle to deep layers of the sea. This genus is related to Mesosagitta very closely. 
General body features and the inhabiting layer are quite similar in these two genera which might be better united into a single genus.

52. S. planctonis (Steinhaus, 1896)

Sagitta planctonis STEINHAUS, 1896

? Sagitta moreauensis GRAY, 1923

53. S. zetesios (Fowler, 1905)

Sagitta Zetesios FOWLER, 1905

54. S. marri (DAvid, 1956)

Sagitta marri DAVID, 1956

(12) Genus Caecosagitta nov.

The central nuclear and the peripheral cortical regions are not differentiated in the eye, hence no pigments are found there. Lateral fins are nearly wholly rayed. Intestinal diverticula are absent. A single species from the deep water.

55. C. macrocephala (Fowler, 1905)

Sagitta macrocephala FOWLER, 1905

(13) Genus Flaccisagitta nov.

The body is flaccid without exception. The corona ciliata is short and confined to the head, starting just behind the brain and stretching to the neck. Intestinal diverticula absent. There is a distinctive rayless-zone on each lateral fin.

56. F. hexaptera (D'ORBIGNY, 1834-44)

Sagitta hexaptera D'ORBIGNY, 1834-44

*Sagitta exaptera D'ORBIGNY, 1834-44

*? Sagitta darwini GRASSI, 1883

*? Sagitta diptera D'ORBIGNY, 1834-44

Sagitta fowleri BENHAM, 1912

*Sagitta longidentata GRASSI, 1881

*Sagitta magna LANGERHANS, 1880

Sagitta hexaptera f. magna Germain \& Joubin, 1916

*Sagitta Mediterranea FORBES, 1843

*Sagitta tricuspidata KENT, 1870

*Sagitta triptera D'ORBIGNY, 1834-44

57. F. enflata (GRAssi, 1881)

Sagitta enflata Grassi, 1881

Sagitta inflata RITTER-ZÁHONY, 1908

*Sagitta australis JohNSTON, 1909

*Sagitta brachycephala MolTschanoff, 1907

*Sagitta flaccida CONANT, 1896 
58. F. gardineri (DONCASTER, 1902)

Sagitta gardineri DONCASTER, 1902

Sagitta inflata, gardineri-type: RITTER-ZÁHONY, 1909

Sagitta enflata f. gardineri: TокIоKA, 1959

59. F. lyra (KROHN, 1853)

Sagitta lyra KROHN, 1853

*Sagitta furcata STeInhaUs, 1896

Pseudosagitta grimaldii GERMAIN \& JoUBIn, 1912

60. F. scrippsae (Alvariño, 1962)

Sagitta scrippsae ALVARIÑo, 1962

61. F. gazellae (RITTER-ZÁHONY, 1909)

Sagitta gazellae RITTER-ZÁHONY, 1909

62. F. maxima (CONANT, 1896)

Spadella maxima CONANT, 1896

*Sagitta gigantea $\mathrm{BROCH}, 1906$

*Sagitta Whartoni FowLER, 1896

Smaller mature individuals of $F$. enflata were ever separated from those of usual body size (forma typica) by RitTER-ZÁHONY* (1909, p. 47) and named forma minor. This distinction will be significant if occurrences of these two forms are separated from each other. F. gardineri differs from enflata in having longer ovaries, while the length of mature ovary seems quite discontinuous between these two species. In some individuals of $F$. lyra the arrangement of lateral fins resembles closely that of $F$. gazellae, the anterior and posterior fins not being combined with each other by a low rayless elevation. Such individuals are gazellae-forms of $F$. lyra and distinctly differ from genuine $F$. gazellae (see p. 337). F. scrippsae is related very closely to $F$. lyra, but it is said that the species is provided with a distinctive collarette around the neck. This feature is quite exceptional for members of this genus. If the existence of the collarette is ascertained by successive authors, then this species must be recognized as a distinct species, as the distribution is confined to the subarctic waters of the North Pacific.

IV. Family Pterosagittidae nov. One pair of lateral fins, each beginning at the trunk-tail septum. The massive collarette is developed along the body sides, and there is a tuft of small tentacular protuberances on each lateral side at the level of the ventral ganglion.

\section{(14) Genus Pterosagitta CosTa, 1869}

The corona ciliata is oval, longer than wide, and stretched below the level

* Ritter-ZÁHony, R. (1909): Chätognathen. Zool. Ergebn. d. Exped. S.M.S. Pola in das Rote Meer 1895-1898. Denkschr. Akad. Wiss. Wien, Vol. 84. (Through Ritter-ZÁHony, 1910). 
of the neck. Lateral fins are rayed thoroughly.

\author{
63. P. draco (KROHN, 1953) \\ Sagitta draco KROHN, 1853 \\ Pterosagitta besnardi VANNUCCI \& HosOe, 1952 \\ Dracochaetus Krohni ABRIC, 1905 \\ *Pterosagitta mediterranea A. CostA, 1869 \\ Dracochaetus Strodtmanni ABRIC, 1905 \\ *Spadella Vougai BÉRANECK, 1895
}

\title{
Suborder Flabellodontina
}

V. Family Krohnittidae nov. One pair of lateral fins, each beginning above the trunk-tail septum. The shape of the tail fin differs slightly from that in other families.

\section{(15) Genus Krohnitta RITTER-ZÁHONY, 1910}

The corona ciliata is short and begins at the level of the neck. Distinct rayless-zone is found on the lateral fin.

64. K. subtilis (GRAssI, 1881)

Sagitta Suptilis GRASSI, 1881

65. K. pacifica (AIDA, 1897)

Krohnia pacifica AIDA, 1897

Krohnitta kerberti OYE, 1918

Krohnia viridis AIDA, 1897

In all, 5 families, 15 genera and 65 taxa are included in Class Sagittoidea. Of 65 taxa, three are defined as subspecies, one as variety and three as forma, thus 58 are recognized as species. The type species of respective genera are represented by the first one of the species list, and the same as to the families. The establishment of forma, variety or subspecies based on minute morphological differences and the separation of species due to so exact differences found in the body appearance may be accused for their making the taxonomy of Chaetognatha complicated. Nevertheless, such distinctions must be very significant when they are noted in relation to the speciation of Chaetognatha or to the distribution of water masses in oceans. Apart from the problems of ranking these taxa, further efforts are desirable to confirm such exact morphological differences and to clarify the causes of such variations.

The following eleven species are still left as doubtful species.

1. Sagitta britannica ForBes, 1843

2. Sagitta gegenbauri Fol, 1879

3. Sagitta helgolandica R. LeUckaRT, 1857

4. Sagitta coreana Moltschanoff, 1907 
5. Sagitta levis GaLzow, 1909

6. Sagitta longicauda GaLzow, 1909

7. Sagitta orientalis MolTschanofF, 1907

8. Spadella musculosa Doncaster, 1903 (see p. 342)

9. Spadella profunda Doncaster, 1903 (see p. 342)

10. Zahonya cestoda Oye, 1918 (see p. 343)

11. Krohnittella boureei GERMAN \& JoUbIN, 1912 (see p. 343)

As stated in my previous paper (1952, pp. 311-312) Sagitta longicauda is related closely to Aidanosagitta crassa and Sagitta coreana and S. levis resemble f. naikaiensis of the same species, while S. orientalis and again S. levis bear some resemblances to Parasagitta elegans. Anyhow, the reexamination of type specimens is the only way to solve the questions about these species.

Before closing this taxonomical note on Chaetognatha, I want to express here my hearty thanks to Dr. T. KomaI, professor emeritus of Kyoto University, who offered me the theme "the systematic study of Chaetognatha" when I graduated from the Zoological Institute of Kyoto University and was going to the former Mitsui Institute of Marine Biology twenty-eight years ago and since then has encouraged me and also given me adequate advices at times. But for his kind teaching and help in earlier stages of this study, I would not be able to reach the present level to propose here a new taxonomical system of Chaetognatha. $(1964,11,20)$

\section{REFERENCES}

Abric, P. (1905) : Sur la systematique des chaetognathes. Comptes Rendues Acad. Sc. Paris, Vol. 141, pp. 222-224.

Alvariño, A. (1961) : Two new chaetognaths from the Pacific. Pacific Science, Vol. 15, No. 1, pp. $67-77$.

(1962): Two new Pacific chaetognaths. Their distribution and relationship to allied species. Bull. Scripps Inst. Oceanogr., Vol. 8, No. 1, pp. 1-50.

(1962 a): Taxonomic revision of Sagitta robusta and Sagitta ferox DonCASTER, and notes on their distribution in the Pacific. Pacific Science, Vol. 16, No. 2, pp. 186-201.

(1963) : Quetognatos epiplanctonicos del mar de Cortes. Revista Soc. Mexicana Hist. Nat., Vol. 24, pp. 97-203.

BAInBRidge, V. (1960): The plankton of inshore waters off Freetown, Sierra Leone. Colonial Office, Fishery Publications, No. 13, 48 pp.

BIERI, R. (1957) : The chaetognath fauna off Peru in 1941. Pacific Science, Vol. 11, No. 3, pp. 255-264.

Burfield, S. T. (1927) : Sagitta. L.M.B.C. Memoirs, 28.

Claus, C. and K. GrobBeN (1905) : Lehrbuch der Zoologie. N. G. Elwert'sche Verlagsbuchhandl., Marburg in Hessen.

DAvid, P. M. (1955): The distribution of Sagitta gazellae RITTER-ZÁHONY. Discovery Reports, Vol. 27, pp. 235-278.

Vol. 4, No. 8, pp. 437-452. 
David, P. M. (1958): A new species of Eukrohnia from the southern ocean with a note on fertilization. Proc. Zool. Soc. London, Vol. 131, Part 4, pp. 597-606.

(1958 a): The distribution of the Chaetognatha of the southern ocean. Discovery Reports, Vol. 29, pp. 199-228.

Doncaster, L. (1903): In Lo Blanco, S.-Le pesche abissali esequite da F. A. Krupp col yacht Puritan nelle adiacenze di Capri ed in altre località del Mediterraneo. Mittheil. Zool. Stat. Neapel, Vol. 16.

Dunbar, M. J. (1962): The life cycle of Sagitta elegans in Arctic and Subarctic seas, and the modifying effects of hydrographic differences in the environment. Jour. Mar. Res., Vol. 20, No. 1, pp. 76-91.

FAGetti Guaita, E. (1958): Quetognato nuevo procedente del Archipelago de Juan Fernandez. Revista Biol. Mar. Valparaiso, Vol. 8, Nos. 1-3, pp. 125-131.

Fraser, J. H. (1961) : Nigerian Chaetognatha-Sagitta friderici R. Z. Ann. Mag. Nat. Hist., Ser. 13, Vol. 3, pp. 289-290.

FuRnestin, M.-L. (1958): Les variations morphologiques de Sagitta setosa Müller et ses rapports avec deux especes voisines. Rev. Trav. Inst. Péches Marit., Vol. 22, Fasc. 2, pp. 211223.

(1959) : Campagne de la "Calypso": Golfe de Guinée. 8 Chaetognathes. Résult. Scient. Campagn. "Calypso", Fasc. 4, pp. 219-233.

(1960): Observations sur quelques échantillons de zooplancton d'Afrique occidentale. Bull. I.F.A.N., Sér. A, Vol. 22, No. 1, pp. 142-151.

(1962): Peches planctoniques, superficielles et profondes, en mediterrance

occidentale. III. Chaetognathes. Rev. Trav. Inst. Péches Marit., Vol. 26, Fasc. 3, pp. 357-368. (1962 a) : Compléments a l'etude de Sagitta euxina variété de Sagitta setosa. Rapp. Proc.-Verb. d. Réunions d. 1. C.I.E.S.M.M., Vol. 16, Fasc. 2, pp. 97-101.

(1962 b) : Chaetognathes des côtes africaines. Exped. Oceanogr. Eaux Cotieres Africaines de l'Atlantique Sud, 1948-49, Rés. Sci., Vol. 3, Fasc. 9, 54 pp.

GermatN, L. and L. JoUbIN (1912) : Note sur quelques chétognathes nouveaux des croisières de S.A.S. le Prince de Monaco. Bull. Inst. Océanogr., No. 228.

Hsü, F. (1943) : On some species of Sagitta of China. Sinensia, Vol. 14, Nos. 1-6, pp. 129-139. HymaN, L. H. (1959): The Invertebrates, Small coelomate groups. Vol. 5, McGraw-Hill, pp. $1-71$.

Mawson, P. M. (1944): Some species of the chaetognath genus Spadella from New Scuth Wales. Trans. Roy. Soc. South Australia, Vol. 30, pp. 327-333.

Owre, H. B. (1963): The genus Spadella (Chaetognatha) in the western North Atlantic Ocean, with descriptions of two new species. Bull. Mar. Sci. Gulf and Caribb., Vol. 13, No. 3 pp. 378-390.

OWRE, H. B. and F. M. BAYER (1962): The systematic position of the middle Cambrian fossil Amiskwia WalcotT. Jour. Paleontology, Vol. 36, No. 6, pp. 1361-63.

Oye, P. (1918) : Untersuchungen über die Chaeotognathen des Javameeres. Contrib. a la Faune des Indes Néerlandaises, Fasc. 4.

Pathansali, D. and T. Tokioka (1963): A new chaetognath, Sagitta johorensis n. sp., from Malay waters. Publ. Seto Mar. Biol. Lab., Vol. 11, No. 1, pp. 105-107.

PierCe, E. L. (1951): The Chaetognatha of the west coast of Florida. Biol. Bull., Vol. 100, No. 3, pp. 206-228.

(1953): The Chaetognatha over the continental shelf of North Calolina with attention to their relation to the hydrography of the area. Sears Found. Jour. Mar. Res., Vol. 12 , No. 1 , pp. $75-92$.

(1958): The Chaetognatha of the inshore waters of North Carolina. Limnol. Oceanogr., Vol. 3, pp. 166-170.

(1962) : Chaetognatha from the Texas coast. Publ. Inst. Mar. Sci. Univ. Texas, Vol. 8, pp. 147-152. 
Prado, M. S. D. A. (1960): A new species of Sagitta from the southern Brazilian coast. Academia Brasileira de Ciencias, Vol. 32, No. 2, pp. 275-280.

RITTER-ZÁHONY, R. (1910) : Westindische Chätognathen. Zool. Jahrb., Suppl. Vol. 11, pp. 133144.

(1911) : Revision der Chätognathen. Deutsch. Südpol.-Exped., 1901-3, Vol. 13 (Zool., Vol, 5), Part 1.

SoARES, N. T. (1961) : Notas gerais sobre morfologia, ecologia, sistematica e importancia do estudo dos quetognatas. Notas Mimeografadas do Centro de Biologia Piscatoria, Lisboa, No. 20, 24 pp.

SuÁres CAABro, J. A. (1955) : Quetognatos de los mares Cubanos. Mem. Soc. Cubana Hist. Nat., Vol. 22, No. 2, pp. 125-180.

SuÁrez CaApro, J. A. and J. E. MAdruga (1960): The Chaetognatha of the north-eastern coast of Honduras, Central America. Bull. Mar. Sci. Gulf Caribb., Vol. 10, No. 4, pp. 421-429.

Sund, P. N. (1961) : Two new species of Chaetognatha from the waters off Peru. Pacific Science, Vol. 15, pp. 105-111.

Thomson, J. M. (1947) : The Chaetognatha of southeastern Australia. Council Sci. Ind. Res. Australia, Bull., No. 222, 43 pp.

TokiokA, T. (1942): Systematic studies of the plankton organisms occurring in Iwayama Bay, Palao. III. Chaetognaths from the Bay and adjacent waters. Palao Trop. Biol. Stat. Studies, Vol. 2, No. 3, pp. 527--548.

(1952): Chaetognaths of the Indo-Pacific. Annot. Zool. Japon., Vol. 25, Nos. 1-2, pp. $307-316$.

(1955): Notes on some chaetognaths from the Gulf of Mexico. Bull, Mar. Sci. Gulf Caribb., Vol. 5, No. 1, pp. 52-65.

(1959): Observations on the texonomy and distribution of chaetognaths of the North Pacific. Publ. Seto Mar. Biol. Lab., Vol. 7, No. 3, pp. 349-456.

No. $55,16 \mathrm{pp}$

(1961): Notes on Sagitta friderici RITTER-ZÁHONY collected off Peru. Postilla,

TOKIOKA, T. and D. PATHANSALI (1963): Another new chaetognath from Malay waters, with a proposal of grouping some species of Sagitta into subgenera. Publ. Seto Mar. Biol. Lab., Vol. 11, No. 1, pp. 119-123.

and ___ (1964) : Spadella cephaloptera forma angulata raised to the rank of species. Publ. Seto Mar. Biol. Lab., Vol. 12, No. 2, pp. 145-148.

VANNuCcI, M. and K. Hosoe (1952) : Resultados cientificos do cruzeiro do "Baependi" e do "Vega" á I. da Trinidade. Chaetognatha. Bolet. Inst. Oceanogr. São Paulo, Vol. 3, Fasc. 1-2, pp. 5-30.

WalcotT, C. D. (1911) : Middle Cambrian annelids. Smiths. Miscell. Coll., Vol. 57, No. 5.

(For further taxonomical references see ALVARIÑo, 1963 and TokIOKA, 1952, 1959 and 1961.)

\section{N D E X}

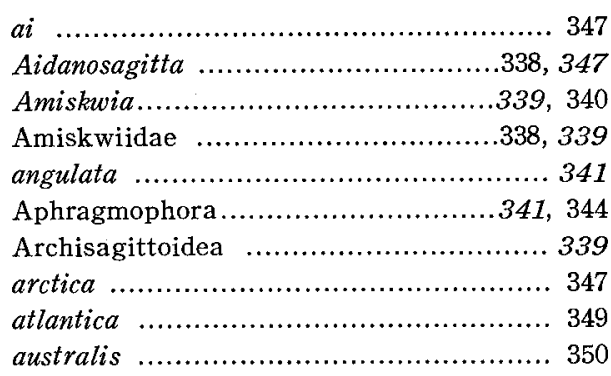

bathyantarctica

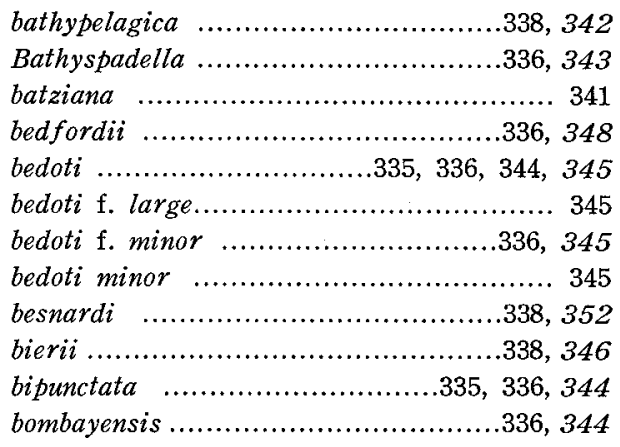


boureei

$336,343,353$

brachycephala 350

britannica $335,337,352$

Caecosagitta 350

californica 344

cephaloptera cephaloptera f. angulata $335,336,341,342,344$ cestoda 338,341

claparedi $337,343,353$

Conantochaetus 341

coreana.

$335,336,352$

crassa $336,348,353$

crassa f. naikaiensis $336,348,349,353$

crassa f. tumida

Ctenodontina $.341,344$

darwini. $.335,350$

decipiens

$.335,336,349$

delicata 336,348

demipenna

$.338,348$

diptera $.335,350$

draco $.335,336,352$

Dracochaetus 339

edentata 336,343

elegans $335,336,344,346,353$

elegans arctica

.. 347

elegans baltica 347

elegans f. baltica

.. 347

enflata

$335,336,350$

enflata f. gardineri ......................... 351

enflata f. minor ............................ 351

equatoria .................................... 347

Eukrohnia ....................335, 336, 338, 342

Eukrohniidae ................................ 342

euneritica ...............................338, 344

euxina .........................335, 336, 337, 344

exaptera .................................. 350

falcidens ................................... 346

ferox..................................336, 343, 347

ferox f. americana......................338, 347

Flabellodontina ........................341, 352

flaccida (of CONANT) ...................... 350

flaccida (of GALzow) ...................... 346

Flaccisagitta ............................... 350

foliacea (=foliaceus) .................... 342

fowleri (Eukrohnia) ........335, 336, 337, 342

fowleri (Sagitta) .......................... 350

friderici ...........................335, 336, 344 furcata ...................................... 351

gallica ....................................... 341

gardineri ................................. 351

gardineri-type of inflata ................... 351

Gastroproctidae ............................ 339

gazellae ...........................335, 337, 351

gazellae-form of lyra.....................337, 351

gegenbauri .......................335, 337, 352

germanica ................................344, 346

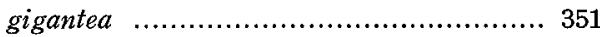

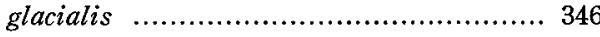

gloriae .................................338, 347

Gourretochaetus ............................... 339

gracilis....................................... 346

Grassiochaetus ........................... 339

grimaldii ................................... 351

hamata ...........................335, 336, 342

hamata var. antarctica ..................... 342

hamata var. borealcs......................... 342

helenae ...............................335, 336, 344

helgolandica $\ldots . . \ldots \ldots \ldots \ldots \ldots \ldots . . . . . . .335,337,352$

Heterokrohnia......................335, 336, 342

hexaptera ...................335, 336, 344, 350

hexaptera f. magna ......................... 350

hispida .............................335, 337, 347

hispida americana ........................ 347

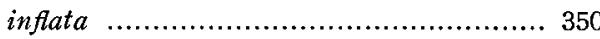

japanica ................................... 347

johnstoni ...............................337, 342

johorensis............................338, 348

kerberti....................................... 352

krohni ....................................... 339

Krohnia ................................... 342

Krohnitta ...................335, 336, 341, 352

Krohnittella .......................336, 343, 353

Krohnittidae ............................... 352

Krohnochaetus................................ 339

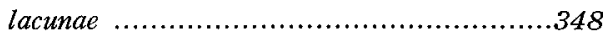

levis ...............................335, 336, 353

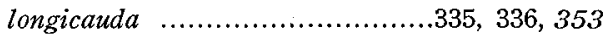

longidentata................................ 350

lyra ...........................335, 336, 337, 351

Lyrochaetus ............................... 339

macrocephala .......................335, 336, 350 


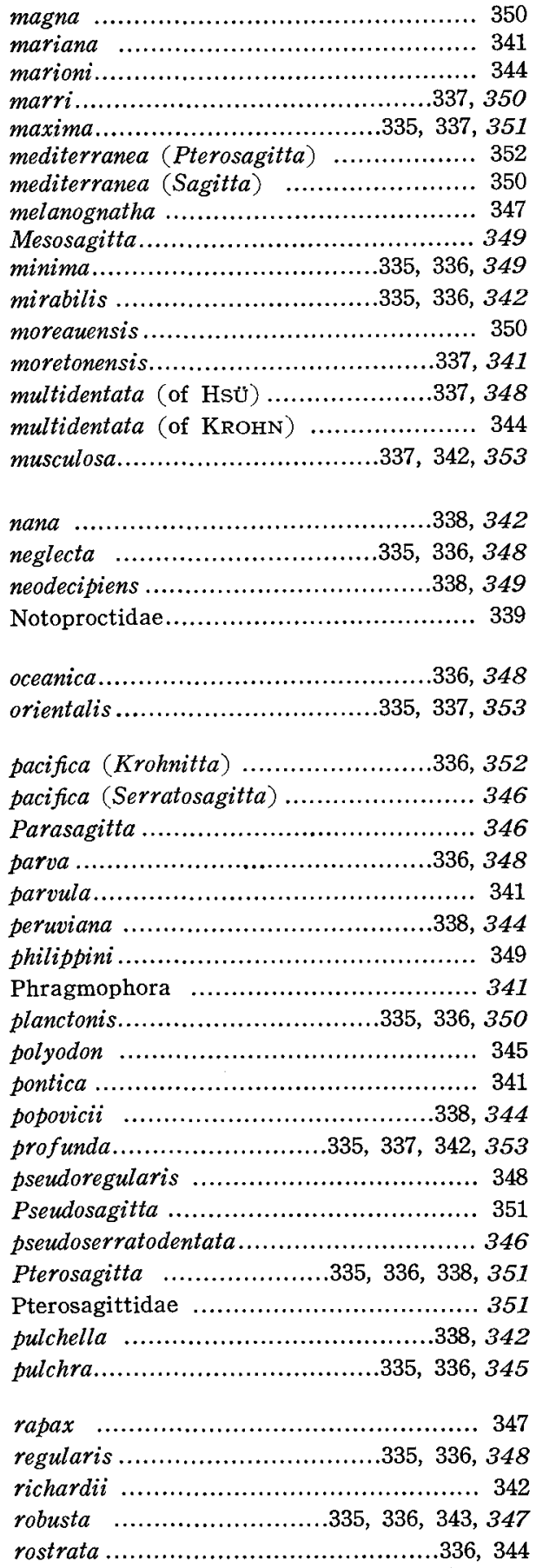

Sagitta............. 335, 336, 338, 340, 344, 352
Sagittidae.

$.338,344$

sagittiformis ....................................... 339

Sagittochaetus ....................................... 339

Sagittoidea …..............................338, 340

schizoptera ..........................335, 336, 342

scrippsae .....................................338, 351

Scottochaetus ...................................... 339

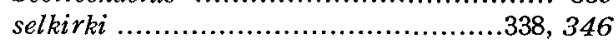

septata ............................................ 348

serratodentata .................................335, 345

serrato-dentata ................................. 345

serratodentata atlantica ....................... 346

serratodentata atlantica f. pseudoserratodentata ....................................336, 346

serratodentata atlantica f. tasmanica...336, 346 serratodentata atlantica f. typica .......336, 346

serratodentata f. atlantica ..................... 346

serratodentata f. pacifica ......................... 346

serratodentata pacifica .....................336, 346

serratodentata pseudoserratodentata ......... 346

serratodentata tasmanica ....................... 346

Serratosagitta ..............................338, 345

serrulata ....................................... 346

setosa ............................335, 336, 337, 344

setosa var. euxina ............................. 344

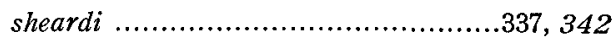

sibogae ................................................ 349

Solidosagitta ................................. 349

Spadella ..............335, 336, 338, 340, 341, 353

Spadellidae ...................................... 341

Spadellochaetus ................................... 339

strodtmanni ...................................... 339

subtilis...............................335, 336, 352

suptilis ........................................... 352

tasmanica........................................ 346

tenuis ............................. 336, 337, 344

trichodermis ................................. 348

tricuspidata ..................................... 350

triptera ........................................... 350

tropica ......................................336, 348

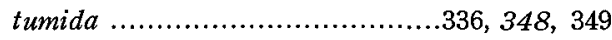

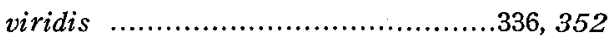

vougai ........................................ 352

weberi …......................................... 345

whartoni ….................................... 351

Zahonya ..............................337, 343, 353

zetesios ......................................337, 350

Zonosagitta ........................................ 345 